Abstracta Iranica Iranica

Revue bibliographique pour le domaine irano-aryen

Volume 32-33 | 2013

Comptes rendus des publications de 2009-2010

\title{
Anna Cannavo. Les royaumes chypriotes entre Perses, Grecs et Phéniciens : factoïdes à Chypre vingt-cinq ans après Maier
}

\section{Astrid Nunn}

\section{(2) OpenEdition \\ 1 Journals}

Édition électronique

URL : http://journals.openedition.org/abstractairanica/40219

DOI : 10.4000/abstractairanica.40219

ISSN : 1961-960X

Éditeur :

CNRS (UMR 7528 Mondes iraniens et indiens), Éditions de l'IFRI

Édition imprimée

Date de publication : 1 décembre 2013

ISSN : 0240-8910

Référence électronique

Astrid Nunn, « Anna Cannavo. Les royaumes chypriotes entre Perses, Grecs et Phéniciens : factoïdes à Chypre vingt-cinq ans après Maier », Abstracta Iranica [En ligne], Volume 32-33 | 2013, document 47, mis en ligne le 01 juillet 2016, consulté le 28 septembre 2020. URL : http://journals.openedition.org/ abstractairanica/40219; DOI : https://doi.org/10.4000/abstractairanica.40219

Ce document a été généré automatiquement le 28 septembre 2020.

Tous droits réservés 


\title{
Anna Cannavo. Les royaumes chypriotes entre Perses, Grecs et Phéniciens : factoïdes à Chypre vingt- cinq ans après Maier
}

\author{
Astrid Nunn
}

\section{RÉFÉRENCE}

Anna Cannavo. « Les royaumes chypriotes entre Perses, Grecs et Phéniciens : factoïdes à Chypre vingt-cinq ans après Maier ». Trans., 39, 2010, p. 49-68.

1 En 1985 F.G. Meier introduisait le concept de factoïde, c'est-à-dire de spéculations répétées si souvent qu'elles deviennent vérité. La place occupée par Chypre à l'intérieur de la Cinquième Satrapie, sa politique, tout particulièrement la forme monarchique de ses cités et ses rapports administratifs ou fiscaux restent très débattus. Mais heureusement ce dossier est devenu plus consistant grâce aux nombreuses études de ces dernières années. La suprématie occasionnelle de Salamine sous le règne d'Évagoras ou le renforcement progressif de Kition sont des éléments d'une mosaïque à géométrie variable, où les intérêts politiques sont de loin plus forts que les aspects ethniques. L'existence de conflits culturels et ethniques est un des factoïdes que l'A. refuse. 


\section{AUTEURS}

\section{ASTRID NUNN}

Université de Munich 